Article

\title{
The Roles of Spinochromes in Four Shallow Water Tropical Sea Urchins and Their Potential as Bioactive Pharmacological Agents
}

\author{
Lola Brasseur ${ }^{1, *}$, Elise Hennebert ${ }^{2}$, Laurence Fievez ${ }^{3}$, Guillaume Caulier ${ }^{1}$, Fabrice Bureau ${ }^{3}$, \\ Lionel Tafforeau ${ }^{2}$, Patrick Flammang ${ }^{1}$, Pascal Gerbaux ${ }^{4}$ and Igor Eeckhaut ${ }^{1, *}$ \\ 1 Biology of Marine Organisms and Biomimetics Unit, Research Institute for Biosciences, \\ University of Mons (UMONS), 23 Place du Parc, B-7000 Mons, Belgium; \\ guillaume.caulier@umons.ac.be (G.C.); patrick.flammang@umons.ac.be (P.F.) \\ 2 Cell Biology Unit, Research Institute for Biosciences, University of Mons (UMONS), 23 Place du Parc, \\ B-7000 Mons, Belgium; elise.hennebert@umons.ac.be (E.H.); lionel.tafforeau@umons.ac.be (L.T.) \\ 3 Cellular and Molecular Immunology Service, Giga Research, University of Liège (ULG), \\ 1 Quartier HOPITAL, 11 Avenue de l'hôpital, B-4000 Liège, Belgium; laurence.fievez@ulg.ac.be (L.F.); \\ fabrice.bureau@ulg.ac.be (F.B.) \\ 4 Organic Synthesis and Mass Spectrometry Laboratory, Research Institute for Biosciences, \\ University of Mons (UMONS), 23 Place du Parc, B-7000 Mons, Belgium; pascal.gerbaux@umons.ac.be \\ * Correspondence: lola.brasseur@gmail.com (L.B.); igor.eeckhaut@umons.ac.be (I.E.); \\ Tel.: +32-(0)65-373433 (L.B.); +32-(0)65-373470 (I.E.)
}

Received: 10 May 2017; Accepted: 12 June 2017; Published: 16 June 2017

\begin{abstract}
Spinochromes are principally known to be involved in sea urchin pigmentation as well as for their potentially interesting pharmacological properties. To assess their biological role in sea urchin physiology, experiments are undertaken on crude extracts from four species and on four isolated spinochromes in order to test their antibacterial, antioxidant, inflammatory and cytotoxic activities. First, the antibacterial assays show that the use of crude extracts as representatives of antibacterial effects of spinochromes are inaccurate. The assays on purified spinochromes showed a decrease in the growth of four strains with an intensity depending on the spinochromes/bacteria system, revealing the participation of spinochromes in the defense system against microorganisms. Secondly, in the 2,2-diphenyl-1-picrylhydrazyl antioxidant assays, spinochromes show an enhanced activity compared to the positive control. This latter observation suggests their involvement in ultraviolet radiation protection. Third, spinochromes present a pro-inflammatory effect on lipopolysaccharide-stimulated macrophages, highlighting their possible implication in the sea urchin immune system. Finally, cytotoxicity assays based on Trypan blue exclusion, performed in view of their possible future applications as drugs, show a weak cytotoxicity of these compounds against human cells. In conclusion, all results confirm the implication of spinochromes in sea urchin defense mechanisms against their external environment and reveal their potential for pharmacological and agronomical industries.
\end{abstract}

Keywords: spinochromes; antibacterial; antioxidant; cytotoxicity; pro-inflammatory; polyhydroxynaphthoquinones; sea urchin; pigments

\section{Introduction}

Although secondary metabolites remain ill-defined, they are commonly considered as natural and organic molecules that are not directly involved in the growth or in the reproduction of living organisms [1]. Instead, they are known to increase the survival rates of organisms producing them [1]. Secondary metabolites play various roles: they serve as defensive molecules against 
parasites or predators, as mediators between symbiotic organisms [2], as sexual hormones or as transporting agents [1]. Due to their interesting bioactive activities, secondary metabolites are now increasingly considered for applications in pharmacological and agrochemical industries [3] Oceans, covering $71 \%$ of the earth's surface and being the birthplace of life, undoubtedly represent the largest potential reservoir for original and recoverable molecules [4]. Among numerous phyla occurring in marine environments, echinoderms contain many particularly interesting compounds like PolyHydroxyNaphthoQuinones (PHNQ) involved in the sea urchin's pigmentation [4]. Also known as spinochromes or echinochromes, these molecules are present in every organ of sea urchins $[5,6]$ ). About thirty different molecular structures are already identified in the literature and are principally derivatives of polyhydroxy-1,4-naphthoquinones substituted with ethyl, acetyl, methoxy or amino groups. The most common spinochromes are named with letters (Echinochrome A and Spinochromes A-E) [4,7-9].

Although spinochromes are colored molecules, and are hence involved in the pigmentation of sea urchins, their chemical structure suggests other bioactive roles. These functions, although still poorly known, have already been investigated in several studies. Some suggest that spinochromes participate in the defense mechanisms of sea urchins by, for instance, preventing biofilm formation due to their fungicidal and antibacterial activities [10-12]. Their antioxidant potential and their capacity to absorb UV light—which protects sea urchins from UV-induced damages [9,13-20]—have already been reported. Some studies attribute anti-inflammatory effects to spinochromes [21,22], whereas others rather suggest their pro-inflammatory effects $[23,24]$. Finally, another study notes the presence of spinochromes in the gametes and embryos of sea urchins. This presence can also be linked to UV protection since it is harmful for both DNA and RNA, and so has a high importance in embryogenesis $[25,26]$. These bioactive effects have also been studied for medical uses. For instance, the antioxidant effects were investigated to scavenge the reactive oxygen species (ROS) involved in aging processes or in numerous different diseases like cancer, diabetes, degenerative diseases or arteriosclerosis [27-29]. A previous study highlighted that PHNQ from sea urchins reduces the concentration of glucose and enhances the synthesis of phospholipids in the liver [30]. For instance, Echinochrome A is commercialized as Histochrome in Russia, a drug administered against ophthalmic diseases [31] and for the prevention of myocardial infarction [15].

However, even though many studies investigated the biochemical effects of spinochromes, almost all experiments were based on crude extracts and not on isolated spinochromes [12,16,32]. In this case, it is difficult to distinguish between the real role of individual spinochromes and the role of other compounds present in extracts. For this reason, we isolated the different spinochromes' congeners from their crude extracts, after their identification by LC-MS experiments $[17,20,33,34]$. To the best of our knowledge, the isolation and thus the biological assays of isolated spinochromes have not been reported previously.

The general aim of the present study is to compare the spinochromes and their bioactivities from four common regular sea urchins found on coral reef flats in the Indian Ocean: Echinometra mathaei (Blainville, 1825), Diadema savignyi (Audouin, 1809) Tripneustes gratilla (Linnaeus, 1758) and Toxopneustes pileolus (Lamarck, 1816). Although these sea urchins are found in the same habitat, they present contrasted behaviors. The burrowing sea urchin E. mathaei is a dark species digging itself into the basaltic and calcareous rock where it lives $[35,36]$. The black long-spined sea urchin $D$. savignyi is typically found well exposed on mixed sandy substrates and coral substrates [37]. The collector sea urchin T. gratilla is a lighter species living between coral rubble and rocks of reef flats or seagrass beds; it covers the upper surface of its body with pieces of sea grasses and seaweeds [38,39]. Finally, the flower sea urchin T. pilleolus is also a lighter species found in the same micro-habitats as T. gratilla. It also frequently covers the upper surfaces of its body but is often totally covered with small pieces of dead coral that it finds in its surroundings $[40,41]$.

Crude extracts were obtained from the tests and spines of these four sea urchin species and were analyzed by mass spectrometry. The four most abundant spinochromes detected in the extracts from 
E. mathaei were then purified and their bioactive effects were compared to the effects obtained with crude extracts from the four species. Four model experiments were selected to analyze the crude extract and the spinochrome bioactivity. First, we measured the antibacterial activity. The experiments were performed on five bacterial species: two model bacteria and three marine ones known to be involved in biofilm formation [42-44]. Secondly, crude extracts and isolated spinochromes were tested in order to determine their antioxidant potential using the common DPPH inhibition method based on Blois' work in 1958 [45], which consists of the scavenging capacity of antioxidants towards $\alpha, \alpha$-diphenyl- $\beta$-picrylhydrazyl (DPPH). Next, we measured the potential inflammatory impact of isolated spinochromes by the quantification of the tumor necrosis factor (TNF)- $\alpha$ released by lipopolysaccharide-stimulated J774 macrophages [46]. Finally, the cytotoxic effects of isolated spinochromes on HeLa cells were studied by using the Trypan Blue exclusion method, which consists of dead cell coloration by Trypan Blue dye [47-49].

\section{Results}

\subsection{Extraction and Isolation of Spinochromes}

Seven major spinochromes (i.e., major congeners with a concentration superior to $5 \%$ of the total PHNQ of the sea urchin species considered) were identified and quantified by mass spectrometry within all sea urchin species (Table 1): namely, Spinochrome B, two isomers of Spinochrome D, Spinochrome E, one isomer of Spinochrome A, Echinochrome A and Spinochrome C. Six other minor spinochromes were identified but will not be further discussed in the present study; a typical chromatogram can be observed in our previous study [5]. The identification of these pigments was based on the comparison of their elemental compositions based on exact mass measurements with data from the literature $[4,8,20,50,51]$. As identification was based on exact mass measurements; we could not determine which isomer corresponds to the Spinochrome D or A.

Table 1. Major PolyHydroxyNaphthoQuinones (PHNQs) molecules (i.e., representing more than 5\% of the total PHNQ content in the species) detected in crude extracts from tests and spines of the four selected sea urchin species, ranked by increasing molecular weight.

\begin{tabular}{|c|c|c|c|c|c|c|c|}
\hline \multirow{2}{*}{ PHNQ } & \multirow{2}{*}{$\begin{array}{l}\text { Retention } \\
\text { Time (min) }\end{array}$} & \multirow{2}{*}{ MW (U) } & \multirow{2}{*}{$\begin{array}{l}\text { Predicted } \\
\text { Formula A }\end{array}$} & \multicolumn{4}{|c|}{$\begin{array}{c}\text { PHNQ Concentration } \\
\text { (MG of } \text { PHNQ/KG of Dried Tests/Spines) }^{\text {B }}\end{array}$} \\
\hline & & & & E. mathaei & D. savignyi & T. gratilla & T. pileolus \\
\hline Spinochrome B & 2.75 & 222 & $\mathrm{C}_{10} \mathrm{H}_{6} \mathrm{O}_{6}$ & $9.2 \pm 6.9$ & - & - & $4.5 \pm 4.4$ \\
\hline Spinochrome D-Iso 1 & 2.65 & 238 & $\mathrm{C}_{10} \mathrm{H}_{6} \mathrm{O}_{7}$ & - & $1.6 \pm 1.7$ & - & $0.6 \pm 0.8$ \\
\hline Spinochrome D-Iso 3 & 8.65 & 238 & $\mathrm{C}_{10} \mathrm{H}_{6} \mathrm{O}_{7}$ & - & - & $0.1 \pm 0.1$ & - \\
\hline Spinochrome E & 1.73 & 254 & $\mathrm{C}_{10} \mathrm{H}_{6} \mathrm{O}_{8}$ & $4.9 \pm 2.1$ & - & $0.2 \pm 0.2$ & $0.4 \pm 0.6$ \\
\hline Spinochrome A-Iso 2 & 7.95 & 264 & $\mathrm{C}_{12} \mathrm{H}_{8} \mathrm{O}_{7}$ & $13.0 \pm 5.0$ & - & - & $0.6 \pm 0.7$ \\
\hline Echinochrome A & 6.69 & 266 & $\mathrm{C}_{12} \mathrm{H}_{10} \mathrm{O}_{7}$ & $10.3 \pm 2.2$ & $17.6 \pm 8.8$ & $0.1 \pm 0.1$ & $0.2 \pm 0.2$ \\
\hline Spinochrome C & 6.73 & 280 & $\mathrm{C}_{12} \mathrm{H}_{8} \mathrm{O}_{8}$ & $2.4 \pm 1.2$ & - & - & $0.6 \pm 0.9$ \\
\hline
\end{tabular}

The comparison between the four studied sea urchin species showed that the darker sea urchins, E. mathaei and D. savignyi, presented higher PHNQ concentrations in the test and spine extracts than the two lighter sea urchins, T. gratilla and T. pileolus. T. gratilla contained less than $1 \mathrm{mG}$ of total PHNQ by $\mathrm{kG}$ of dried tests/spines. D. savignyi contained mainly one PHNQ, Echinochrome A, and only a few of Spinochrome D - Iso 1. Although T. pileolus presented a large diversity of PHNQs, only Spinochrome B was present at a concentration higher than $1 \mathrm{mG} / \mathrm{kG}$.

The isolation of spinochromes to perform the biochemical assays was carried out on the four most abundant congeners: Spinochrome A, Spinochrome B, Spinochrome E and Echinochrome A. However, Echinochrome A co-elutes with another PHNQ, Spinochrome C (equal to $75 \% / 25 \%$ ratio). The mixture will be considered as an isolated mix. Figure 1 shows the PHNQ structures based on predicted formulae and literature confrontation. 
<smiles>Cc1c(O)c(O)c2c(c1O)C(=O)C(O)=C(O)C2=O</smiles>

Echinochrome A<smiles>CC(=O)OC1=C(O)C(=O)c2c(O)c(O)cc(O)c2C1=O</smiles>

Spinochrome A<smiles>O=C1C(O)=C(O)C(=O)c2c(O)cc(O)cc21</smiles>

Spinochrome B<smiles>CC(=O)OC1=C(O)C(=O)c2c(O)c(O)c(O)c(O)c2C1=O</smiles>

Spinochrome C<smiles>O=C1C(O)=C(O)C(=O)c2c(O)c(O)c(O)c(O)c21</smiles>

Spinochrome E

Figure 1. Structure of isolated E. mathaei tests/spines pigments collected in four fractions with the HPLC.

\subsection{Bioactive Effects of Spinochromes}

\subsubsection{Antibacterial Activity Assay}

The antibacterial activity of tests/spines crude extracts isolated from the four studied sea urchin species and of spinochromes isolated from E. mathaei extracts was tested on five bacterial strains. The effects on the bacterial growth and their calculated $\mathrm{EC}_{50}$ are presented in Figure 2 and Table 2, respectively.

All crude extracts presented antibacterial activity against at least one bacterial strain. E. mathaei crude extracts showed a strong antibacterial activity against all bacteria but appeared to be more efficient against E. coli and B. subtilis $\left(\mathrm{EC}_{50}<800 \mu \mathrm{G} / \mathrm{mL}\right.$ ) than against the other strains $\left(\mathrm{EC}_{50}>1100 \mu \mathrm{G} / \mathrm{mL}\right)$. D. savignyi possessed a strong antibacterial activity against all strains $\left(\mathrm{EC}_{50}<700 \mu \mathrm{G} / \mathrm{mL}\right)$. T. gratilla was active against $B$. subtilis and had a strong activity against $C$. marina $\left(\mathrm{EC}_{50}<544 \mu \mathrm{G} / \mathrm{mL}\right)$. T. pileolus presented a strong activity against $B$. subtilis $\left(\mathrm{EC}_{50}=512 \mu \mathrm{G} / \mathrm{mL}\right)$.

Except for $C$. marina (which was not affected by ampicillin), isolated spinochromes also showed large antibacterial activity. However, several high concentrations were not tested against $V$. aestruanus and C. marina because of the formation of compact bacterial aggregates, making the O.D. measurements impossible. Instead, the mixed bacteria/spinochromes were incubated overnight in fresh medium in order to assess the bacterial death or survival. While the $V$. aestruanus/spinochromes mix did not show any bacterial growth at $1000 \mu \mathrm{M}$, the $C$. marina/spinochromes mix presented a normal bacterial growth at this dose.

The Echinochrome A/Spinochrome $\mathrm{C}$ was strongly active $\left(\mathrm{EC}_{50}<61 \mu \mathrm{M}\right)$. Its $\mathrm{EC}_{50}$ was even lower than that of ampicillin against $S$. oneidensis. Spinochrome A also revealed a relatively strong activity $\left(\mathrm{EC}_{50}<250 \mu \mathrm{M}\right)$. Spinochromes $\mathrm{B}$ and $\mathrm{E}$ presented a more variable activity according to the bacterial strain. They showed a high antibacterial activity against $E$. coli $\left(\mathrm{EC}_{50}<30 \mu \mathrm{M}\right)$, but were less efficient against other strains. As a comparison, ampicillin did not possess antibacterial activity against C. marina and $V$. aestruanus but was strongly active against other strains. 

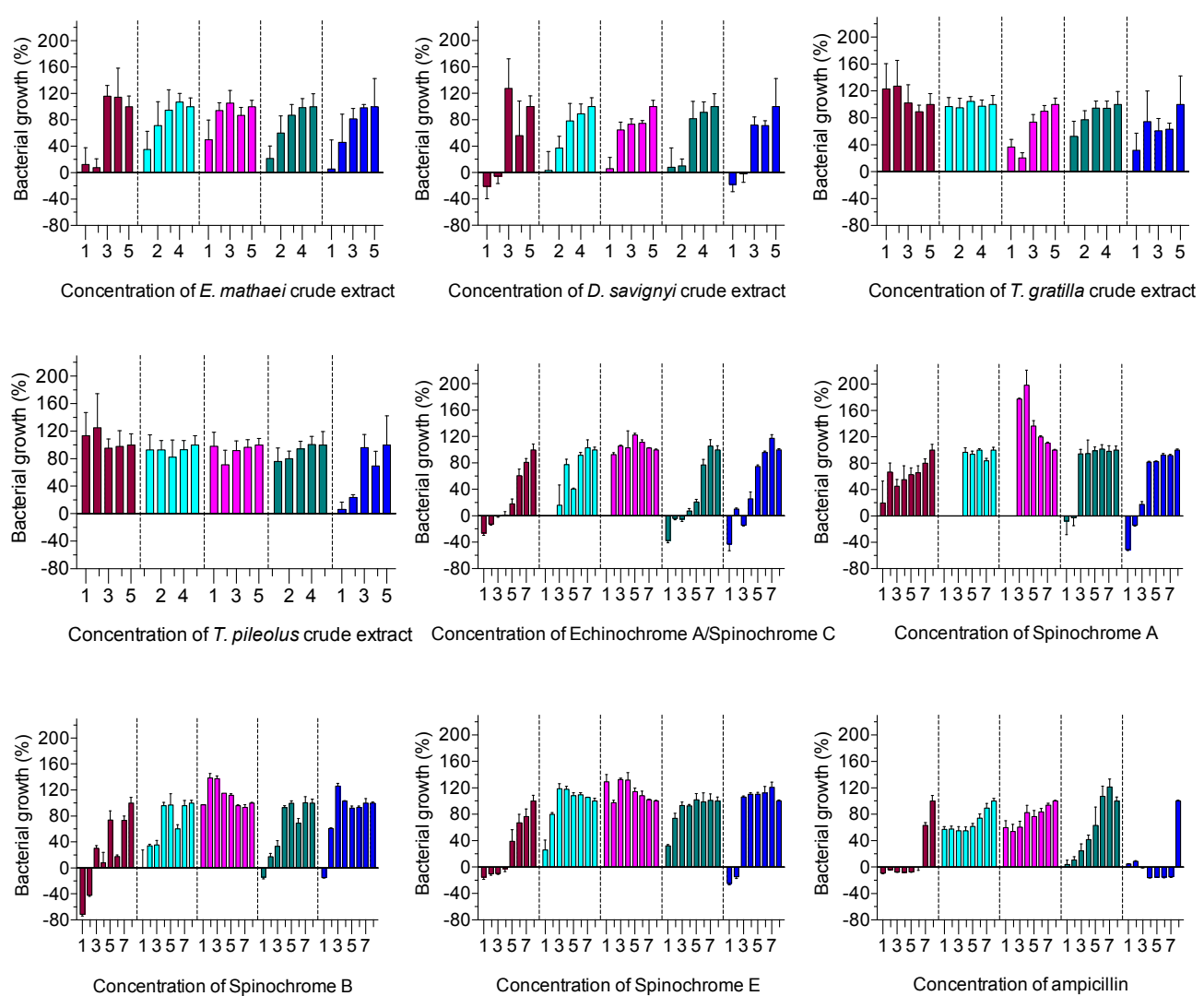

E. coli $\square$ V. aestruanus $\square$ C. marina $\square$ S. oneidensis $\square$ B. subtilis

Figure 2. Growth (\%) of bacteria incubated in medium containing sea urchin crude extracts or isolated spinochromes. Isolated spinochromes and ampicillin concentrations are expressed as $1=1000 \mu \mathrm{M}$; $2=500 \mu \mathrm{M} ; 3=200 \mu \mathrm{M} ; 4=100 \mu \mathrm{M} ; 5=40 \mu \mathrm{M} ; 6=20 \mu \mathrm{M} ; 7=4 \mu \mathrm{M} ; 8=$ Negative control. Crude extract concentrations are expressed as $1=2000 \mu \mathrm{G} / \mathrm{mL} ; 2=1000 \mu \mathrm{G} / \mathrm{mL} ; 3=200 \mu \mathrm{G} / \mathrm{mL} ; 4=100 \mu \mathrm{G} / \mathrm{mL}$; $5=1 \mu \mathrm{G} / \mathrm{mL}$. Data are expressed as the mean \pm one standard deviation of 3 independent experiments for each sample concentration.

Table 2. $\mathrm{EC}_{50}$ and MIC values for antibacterial activity of crude extracts, isolated spinochromes and ampicillin. $\mathrm{EC}_{50}$ and $\mathrm{MIC}$ values for isolated spinochromes and ampicillin are presented in $\mu \mathrm{M}$ and are converted into $\mu \mathrm{G} / \mathrm{mL}$ in order to compare them with crude extracts. "_. was used for spinochrome/bacteria systems where the $\mathrm{EC}_{50}$ or MIC value could not be determined because of bacterial aggregates.

\begin{tabular}{|c|c|c|c|c|c|c|}
\hline & \multicolumn{5}{|c|}{ Antibacterial Activity } & \\
\hline & \multicolumn{5}{|c|}{$\mathrm{EC}_{50}$ and MIC-Bacterial Growth } & \\
\hline & E. coli & B. subtilis & V. aestuarianus & C. marina & S. oneidensis & \\
\hline \multicolumn{7}{|c|}{ Tests/Spines Crude Extracts ( $\mu \mathrm{G} / \mathrm{ML})$} \\
\hline \multirow{2}{*}{ E. mathaei } & 688.40 & 716.70 & 1518.00 & 1995.00 & 1118.00 & $\mathrm{EC}_{50}$ \\
\hline & $>2000$ & $>2000$ & $>2000$ & $>2000$ & $>2000$ & MIC \\
\hline \multirow{2}{*}{ D. savignyi } & 358.70 & 252.40 & 534.80 & 681.00 & 391.00 & $\mathrm{EC}_{50}$ \\
\hline & 406.80 & 1219.00 & $>2000$ & $>2000$ & $>2000$ & MIC \\
\hline \multirow{2}{*}{ T. gratilla } & $>2000$ & 1227.00 & $>2000$ & 543.80 & $>2000$ & $\mathrm{EC}_{50}$ \\
\hline & $>2000$ & $>2000$ & $>2000$ & $>2000$ & $>2000$ & MIC \\
\hline \multirow{2}{*}{ T. pileolus } & $>2000$ & 512.60 & $>2000$ & $>2000$ & $>2000$ & $\mathrm{EC}_{50}$ \\
\hline & $>2000$ & $>2000$ & $>2000$ & $>2000$ & $>2000$ & MIC \\
\hline
\end{tabular}


Table 2. Cont.

\begin{tabular}{|c|c|c|c|c|c|c|c|}
\hline & \multicolumn{5}{|c|}{ Antibacterial Activity } & & \\
\hline & \multicolumn{5}{|c|}{$\mathrm{EC}_{50}$ and MIC-Bacterial Growth } & & \\
\hline & E. coli & B. subtilis & V. aestuarianus & C. marina & S. oneidensis & & \\
\hline \multicolumn{8}{|c|}{ Isolated Spinochromes $(\mu \mathrm{M} ; \mu \mathrm{G} / \mathrm{ML})$} \\
\hline \multirow{4}{*}{$\begin{array}{l}\text { Echinochrome A/ } \\
\text { Spinochrome C }\end{array}$} & 22.56 & 60.98 & - & $>1000$ & 27.88 & $\mu \mathrm{M}$ & $\mathrm{EC}_{50}$ \\
\hline & 6.08 & 16.43 & & $>269$ & 7.51 & $\mu \mathrm{G} / \mathrm{mL}$ & \\
\hline & 54.19 & 149.40 & - & 628.50 & 48.26 & $\mu \mathrm{M}$ & \\
\hline & 14.60 & 40.26 & - & 169.38 & 13.00 & $\mu \mathrm{G} / \mathrm{mL}$ & MIC \\
\hline \multirow{4}{*}{ Spinochrome A } & 199.40 & 139.20 & - & $>1000$ & 238.20 & $\mu \mathrm{M}$ & \\
\hline & 52.64 & 36.75 & - & $>264$ & 62.88 & $\mu \mathrm{G} / \mathrm{mL}$ & $\mathrm{E} \mathrm{C}_{50}$ \\
\hline & $>1000$ & 228.40 & - & $>1000$ & 435.70 & $\mu \mathrm{M}$ & \\
\hline & $>264$ & 60.30 & - & $>254$ & 115.02 & $\mu \mathrm{G} / \mathrm{mL}$ & MIC \\
\hline \multirow{4}{*}{ Spinochrome B } & 16.22 & 510.50 & 214.70 & $>1000$ & 172.40 & $\mu \mathrm{M}$ & $\mathrm{FC}_{-}$ \\
\hline & 3.60 & 113.331 & 47.66 & $>222$ & 38.27 & $\mu \mathrm{G} / \mathrm{mL}$ & EC 50 \\
\hline & 468.30 & 583.50 & $>1000$ & $>1000$ & 238.60 & $\mu \mathrm{M}$ & \\
\hline & 103.96 & 129.54 & $>222$ & $>222$ & 52.97 & $\mu \mathrm{G} / \mathrm{mL}$ & MIC \\
\hline \multirow{4}{*}{ Spinochrome E } & 28.53 & 295.20 & 746.70 & $>1000$ & 742.60 & $\mu \mathrm{M}$ & \\
\hline & 7.25 & 74.98 & 189.66 & $>254$ & 188.62 & $\mu \mathrm{G} / \mathrm{mL}$ & $\mathrm{EC}_{50}$ \\
\hline & 90.33 & 422.40 & $>1000$ & $>1000$ & $>1000$ & $\mu \mathrm{M}$ & \\
\hline & 22.94 & 107.29 & $>254$ & $>254$ & $>254$ & $\mu \mathrm{G} / \mathrm{mL}$ & MIC \\
\hline \multirow{4}{*}{$\begin{array}{l}\text { AMPICILIN } \\
(\mu \mathrm{M} ; \mu \mathrm{G} / \mathrm{ML})\end{array}$} & 4.26 & 1.31 & $>1000$ & $>1000$ & 83.55 & $\mu \mathrm{M}$ & \\
\hline & 1.49 & 0.46 & $>349$ & $>349$ & 65.82 & $\mu \mathrm{G} / \mathrm{mL}$ & $\mathrm{EC}_{50}$ \\
\hline & 8.10 & 1.80 & $>1000$ & $>1000$ & 272.00 & $\mu \mathrm{M}$ & MIC \\
\hline & 2.83 & 0.63 & $>349$ & $>349$ & 94.93 & $\mu \mathrm{G} / \mathrm{mL}$ & MIL \\
\hline
\end{tabular}

\subsubsection{Antioxidant Activity Assay}

The antioxidant activities of test/spines crude extracts isolated from the four studied sea urchin species and of spinochromes isolated from E. mathaei extracts are shown in Figure 3. Their calculated $\mathrm{EC}_{50}$ are presented in Table 3. The major differences appeared between the crude extract activity among the different studied sea urchin species. E. mathaei and D. savignyi crude extracts presented largely higher antioxidant activities than those of T. gratilla and T. pileolus, with a 100\% of DPPH inhibition reached around $150 \mu \mathrm{G} / \mathrm{mL}$ of crude extract for E. mathaei and D. savignyi, and superior to the maximal tested concentrations for T. gratilla and T. pileolus. The calculated $\mathrm{EC}_{50}$ of E. mathaei and D. savignyi crude extracts was around $35 \mu \mathrm{G} / \mathrm{mL}$ (Table 3). The $\mathrm{EC}_{50}$ of T. gratilla and T. pileolus crude extracts, being superior to the tested concentrations, could not be determined. On the contrary, all isolated spinochromes showed high antioxidant effects. The calculated $\mathrm{EC}_{50}$ were similar and even higher than the positive control, i.e., Trolox $(21 \mu \mathrm{M})$ for Spinochrome $\mathrm{E}(11 \mu \mathrm{M})$ and for the Echinochrome A/Spinochrome C $(16 \mu \mathrm{M})$. Spinochrome A and Spinochrome B EC 50 values were quite similar to Trolox, i.e., 22 and $29 \mu \mathrm{M}$, respectively, and thus also presented a very high antioxidant activity. Negative values and values above $100 \%$ on figures are due to the absorbance variabilities and to the calculation method. 
Table 3. $\mathrm{EC}_{50}$ values of antioxidant activity for crude extracts, isolated spinochromes and Trolox. $\mathrm{EC}_{50}$ values for isolated spinochromes and Trolox are presented in $\mu \mathrm{M}$ and are converted into $\mu \mathrm{G} / \mathrm{mL}$ to compare them with crude extracts.

\begin{tabular}{ccc}
\hline & \multicolumn{2}{c}{ Antioxidant Activity } \\
\cline { 2 - 3 } & EC $_{\mathbf{5 0} \text {-DPPH Inhibition }}$ \\
\hline Sea Urchin Crude Extracts & \multicolumn{2}{c}{$(\mu \mathrm{G} / \mathrm{ML})$} \\
\hline E. mathaei & \multicolumn{2}{c}{35.63} \\
D. savignyi & \multicolumn{2}{c}{34.46} \\
T. gratilla & \multicolumn{2}{c}{$>400$} \\
T. pileolus & \multicolumn{2}{c}{$>400$} \\
\hline Isolated Spinochromes & $(\mu \mathrm{M})$ & $(\mu \mathrm{G} / \mathrm{ML})$ \\
\hline Echinochrome A/Spinochrome C & 16.31 & 4.40 \\
Spinochrome A & 22.17 & 5.85 \\
Spinochrome B & 29.38 & 6.52 \\
Spinochrome E & 10.85 & 2.76 \\
TROLOx $(\mu \mathrm{M})$ & 20.88 & 5.22 \\
\hline
\end{tabular}
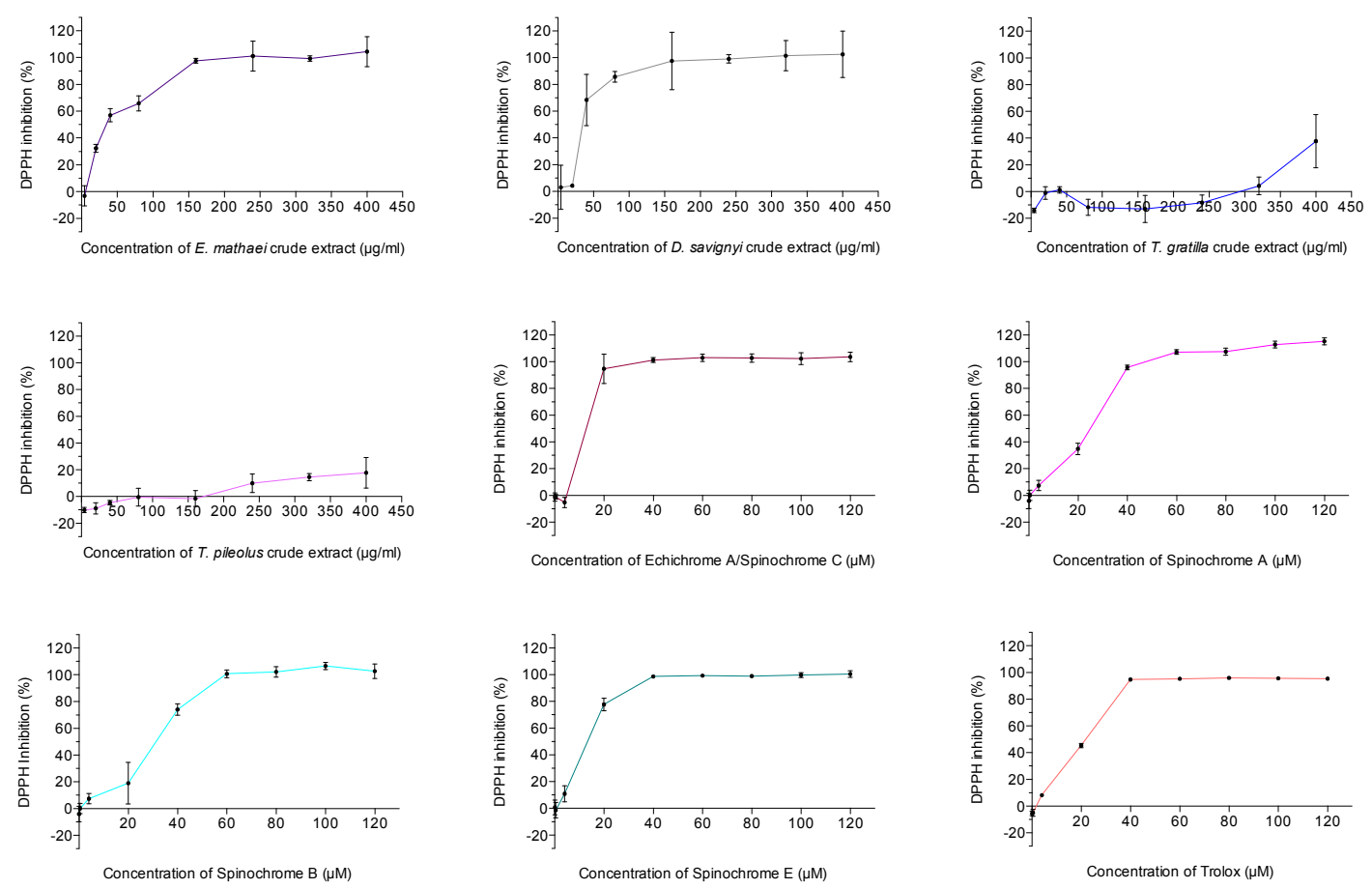

Figure 3. DPPH inhibition (\%) of sea urchin crude extracts $(n=9)$ and isolated spinochromes $(n=6)$. Data are expressed as the means \pm one standard deviation of $n$ independent experiments for each concentration of a sample.

\subsubsection{Inflammatory Activity Assay}

The inflammatory activities of the isolated spinochromes are shown in Figure 4. Pre-incubation of J774 macrophages with each of the isolated spinochromes caused an increase in TNF- $\alpha$ production by these cells after LPS stimulation. Without LPS stimulation, the isolated spinochromes did not have any effect on TNF- $\alpha$ production (data not shown). 


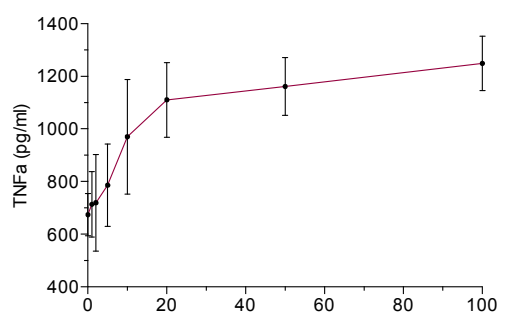

Concentration of Echinochrome A/Spinochrome $\mathrm{C}(\mu \mathrm{M})$

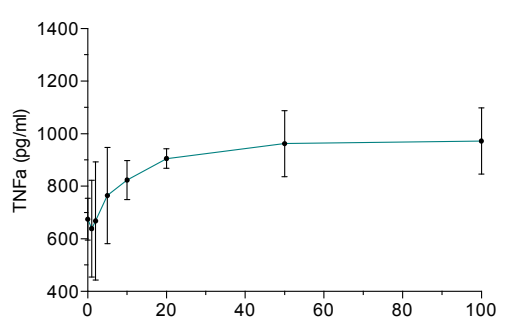

Concentration of Spinochrome $\mathrm{E}(\mu \mathrm{M})$

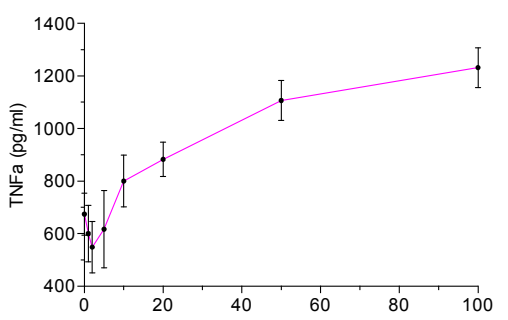

Concentration of Spinochrome A ( $\mu \mathrm{M})$

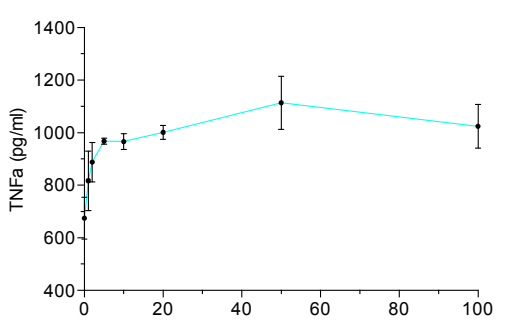

Concentration of Spinochrome B $(\mu \mathrm{M})$

Figure 4. Production of TNF- $\alpha$ by response from J774 macrophages incubated with isolated spinochromes and stimulated with LPS. Data are expressed as the means \pm one standard deviation of 3 independent experiments for each sample concentration.

\subsubsection{Cytotoxic Activity Assay}

The cytotoxic activities of spinochromes were evaluated using Trypan Blue dye, which enables dead cell coloration. The cytotoxic activities of the isolated spinochromes are shown in Figure 5. Their calculated $\mathrm{EC}_{50}$ values are presented in Table 4 . All isolated spinochromes caused a decrease in HeLa cell viability at $500 \mu \mathrm{M}$. Three of them, Spinochromes A and E and the Echinochrome A/Spinochrome $\mathrm{C}$ mix, present a calculated $\mathrm{EC}_{50}$ between $259 \mu \mathrm{M}$ and $381 \mu \mathrm{M}$ (Table 4). The Spinochrome B EC 50 was not calculated since the slope of the cell viability was too slight with the tested concentrations.

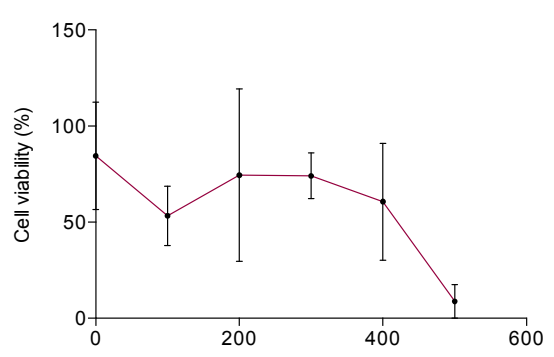

Concentration of Echinochrome A/Spinochrome $\mathrm{C}(\mu \mathrm{M})$

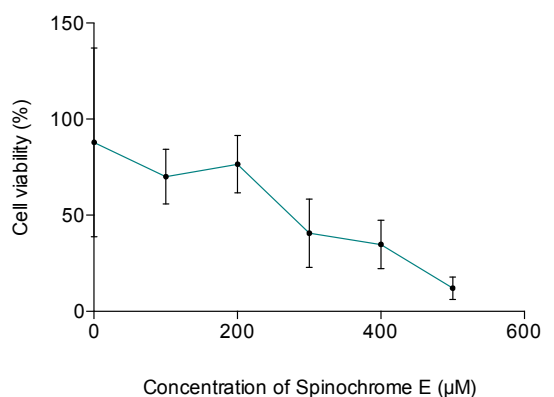

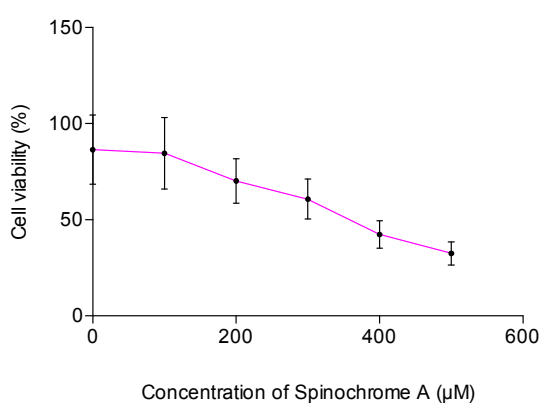

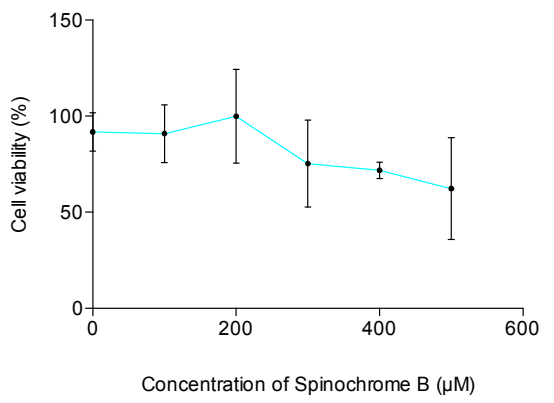

Figure 5. Cell viability (\%) of HeLa cells incubated with increasing doses of isolated spinochromes. Data are expressed as the means \pm one standard deviation of 3 independent experiments for each sample concentration. 
Table 4. $\mathrm{EC}_{50}$ values of cytotoxic activity of isolated spinochromes against HeLa cells.

\begin{tabular}{cc}
\hline & \multicolumn{2}{c}{ Cytotoxic Activity } \\
\cline { 2 - 2 } & $\mathrm{EC}_{50}$-Cell Viability \\
\hline Isolated Spinochromes $(\mu \mathrm{M})$ \\
\hline Echinochrome A/Spinochrome C \\
Spinochrome A & 380.9 \\
Spinochrome B & 341.7 \\
Spinochrome E & $>500$ \\
\hline
\end{tabular}

\section{Discussion}

The spinochromes are red to purple pigments naturally present in all body compartments of sea urchins. Several studies have already highlighted some bioactive properties, which suggest an active role of defense in sea urchins $[10,51,52]$. However, most of the previous research conducted on the bioactivity of spinochromes was based on crude extracts from the tests and spines of sea urchins $[11,12,16,18,20,32]$. The present study, comparing the bioactivity of crude extracts isolated from four studied sea urchins and spinochromes isolated from E. mathaei, showed that the results of bioassays can differ when using crude extracts or purified spinochromes. Therefore, it is a dangerous shortcut to discuss the role of spinochromes when using only crude extracts. This assessment is particularly evident in the species $D$. savignyi. Indeed, $D$. savignyi crude extracts showed a large antibacterial activity against all tested bacterial strains, even though these extracts only contain Echinochrome A that had no effect on C. marina. However, the Echinochrome A isolated does not have an antibacterial activity against $C$. marina. This antibacterial activity against $C$. marina with crude extracts from $D$. savignyi is therefore certainly due to a compound other than spinochromes or a synergic effect between Echinochrome A and another compound.

Tropical shallow water sea urchins are preyed upon by various fishes $[53,54]$ and parasitized by multiple organisms [55-57]. Diseases can also occur in sea urchins and are often induced by predators or parasites. The most common of these diseases is the bald sea urchin disease in which bacteria proliferate in wounds $[58,59]$. Obviously, the tests and spines of the four sea urchin species we tested presented an antibacterial activity but the extracts of two of them, E. mathaei and D. savignyi, appeared more efficient as they decreased the growth of the five tested bacteria at a concentration of $500 \mu \mathrm{G} / \mathrm{mL}$ while at that concentration, T. gratilla and T. pileolus crude extracts only had a significant effect on 2 and 1 bacterial species, respectively. The antibacterial assays performed with isolated spinochromes also showed contrasting results. All spinochromes had an antibacterial activity except against $C$. marina and with an effectiveness depending on the tested spinochrome and the type of bacteria. The mixed Echinochrome $\mathrm{A}$ and Spinochrome $\mathrm{C}$ had the highest activities, being effective on some bacteria already at concentration as weak as $200 \mu \mathrm{M}$ (or $52.8 \mu \mathrm{G} / \mathrm{mL}$ ) Spinochrome A also acted on all strains but at a higher concentration. By contrast, Spinochrome B and Spinochrome E had a lower global activity except against $E$. coli. It is important to highlight that some spinochromes were not completely soluble in water at high concentrations [60], which could lead us to underestimate some results and particularly the antimicrobial ones where high concentrations were tested.

Each spinochrome thus has a specific antibacterial spectrum that may widen the protection of some sea urchins against infections. At the study site, sea urchins are prone to infestation by the gastropod Vexilla vexillum that can lead to lethal bacterial infections. Out of the four studied sea urchins, only T. gratilla and E. mathaei can be infested and develop the disease, the first being 5 times more affected [61]. D. savignyi and T. pileolus are probably better protected than the two other species thanks to their efficient spines or their pedicellariae toxins [62]. Moreover, the spinochrome antibacterial pattern in E. mathaei may explain its better resistance compared to $T$. gratilla to bacteria after the grazing exerted by the gastropod. It was interesting to notice that spinochromes could present a higher antibacterial effect on marine strains than ampicillin: all spinochromes had a higher 
effect on $V$. aestuarianus while the Echinochrome A/Spinochrome $\mathrm{C}$ mix showed a higher effect on S. oneidensis. On the contrary, ampicillin stayed more efficient against model human strains. Subsequently, antibacterial activities, especially observed on marine bacteria, could lead us to consider the spinochromes as potential candidates in the field of marine aquacultures where the resistance to classical antibiotics has dramatically increased during the last years $[63,64]$.

Reactive oxygen species (ROS) are reactive molecules containing oxygen. They are byproducts of the normal metabolism of oxygen and play important roles in cell signaling and homeostasis. With environmental stress (e.g., UV or heat exposure), ROS levels can increase dramatically and may result in significant damages to the cell structure, a phenomenon known as the oxidative stress $[27,28]$. Moreover, ROS are known to cause DNA damages and thus potentially affect reproduction and development [65-68]. Some studies [28,29] showed that antioxidant molecules provide protection against ROS and hence from the resulting cell damages. It is well known that spinochromes are antioxidant agents in sea urchins $[9,12,14,20]$. In the present study, the antioxidant properties of both crude extracts of the four studied sea urchin species and spinochromes isolated from E. mathaei were tested. Results based on crude extracts showed a very weak antioxidant activity for T. gratilla and T. pileolus. Such a low activity provides evidence for the absence of other antioxidant compounds in crude extracts. On the other hand, the two other sea urchins, i.e., the ones that do not show any covering behavior, showed a very high antioxidant activity. The experiments on isolated spinochromes demonstrated that Spinochrome E and Echinochrome A/Spinochrome $\mathrm{C}$ mix are powerful antioxidants, even more efficient than the Trolox control, an analog of vitamin E. Spinochrome antioxidant activities can be linked to their molecular structure and, in particular, to the number of their hydroxyl and acetyl groups. Spinochrome E, with the highest antioxidant activity, has 6 hydroxyl radicals. Echinochrome A and Spinochrome C, the spinochrome with the second highest antioxidant activity, both possess 5 hydroxyl radicals. They are followed by Spinochrome A with 4 hydroxyl groups and one acetyl group. Finally, Spinochrome B has only 4 hydroxyl substituents. These results are confirmed by other studies $[69,70]$ that showed an increase in the antioxidant potential with the number of double bonds, hydroxyls as well as acetyl radicals. This hypothesis could also explain the extremely high antioxidant capacity determined for dimeric spinochromes (with 8 hydroxyl groups) as mentioned in a previous study [21]. The low spinochrome concentrations in T. gratilla and T. pileolus could explain why they cover themselves with various objects; this covering behavior could indeed overcome the lack of spinochromes and protect them against UV radiation.

In vitro inflammatory assays led to unexpected results, in opposition with two studies where the Echinochrome A is known to present anti-inflammatory activities [22,71]. Indeed, these two studies were performed in vivo in order to treat a particular disease and then occurred in a complete metabolism. In our study, however, each isolated spinochrome significantly increased the TNF- $\alpha$ production by LPS-stimulated macrophages, inducing a pro-inflammatory activity. Such results were previously observed in another study, which showed the pro-inflammatory effects of crude extract from sea urchin spines [23], although authors favored the role of proteins in this pro-inflammatory activity. Another study highlighted the pro-inflammatory role of naphthoquinones in mice [72]. Moreover, these results also explain the inflammatory reactions caused by sea urchin injuries when the spine penetration in skin causes edema, erythema and granulomatous inflammation [24]. This synergy with LPS, already shown in the literature with hemoglobin [73], could contribute to inflammatory responses and then to the stimulation of the immune system. Several studies have already observed the LPS effects of sea urchin immune systems, hence showing an increase in coelomocyte recruitment (particularly red spherules cells, which contain spinochromes) and an increase in phagocytosis [74-77].

Based on the present analyses, we found that spinochromes have a moderate antibacterial activity, lower than the ampicillin control for human models but higher for marine ones. However, they present a high antioxidant activity, some spinochromes being even more efficient than the Trolox control. Finally, they induce a synergistic pro-inflammatory response following LPS stimulation. Cytotoxicity assays were then performed on HeLa cells to determine the impact of isolated 
spinochromes on human cells in view of some possible future pharmacological studies. The results show a slight decrease in cell viability at high concentrations. Spinochrome E appears to be the most active compound $\left(\mathrm{EC}_{50}=259 \mu \mathrm{M}\right.$, corresponding to $66 \mu \mathrm{G} / \mathrm{mL}$ ), and Spinochrome $\mathrm{B}$ is the least active compound ( $\mathrm{EC}_{50}>500 \mu \mathrm{M}$, corresponding to $111 \mu \mathrm{G} / \mathrm{mL}$ ). According to cytotoxicity criteria [78], only Spinochrome $\mathrm{E}$ is classified as a moderately cytotoxic compound ( $\mathrm{EC}_{50}<90 \mu \mathrm{G} / \mathrm{mL}$ ). Consequently, Spinochromes A, B and the Echinochrome A/Spinochrome C mix are interesting candidates for their potential effects on human health. Future studies are necessary in order to investigate their real impacts on human cells.

In conclusion, some valuable results can be highlighted from this study. First, the use of test/spine crude extracts is not appropriate to determine the antibacterial effect of spinochromes due to the potential interference of other compounds. However, the antioxidant activities of spinochromes can be approached with crude extracts. Second, spinochromes are more concentrated in sea urchins that do not show any covering behavior, suggesting a link between the two facts. Finally, spinochromes have interesting biochemical activities-like antibacterial, antioxidant and pro-inflammatory effects-affirming their biological role in sea urchin defense mechanisms against their external environment (microorganisms, ROS or UV radiations) as well as in their immune system. If spinochromes do not appear to be highly toxic for human cells, the antioxidant activities represent a high interest in these metabolites as good candidates in pharmacology. The antibacterial activity, especially observed against marine bacteria, could also lead us to consider spinochromes as potential candidates in the field of marine aquaculture.

\section{Materials and Methods}

\subsection{Extraction and Isolation of Spinochromes}

\subsubsection{Sampling}

Four species of sea urchins were randomly collected by snorkeling at high tide around the coral reef of Toliara, Madagascar $\left(23^{\circ} 23^{\prime} 34^{\prime \prime}\right.$ S, $43^{\circ} 38^{\prime} 47^{\prime \prime}$ E) in November 2015: 32 Echinometra mathaei (Blainville, 1825), 5 Diadema savignyi (Audouin, 1809), 5 Tripneustes gratilla (Linnaeus, 1758) and 5 Toxopneustes pileolus were collected (Lamarck, 1816). Their tests with spines (tests/spines hereafter) were dissected not later than $10 \mathrm{~min}$ after sampling. They were washed in cold tap water and dried for $12 \mathrm{~h}$ at $90{ }^{\circ} \mathrm{C}$ in the dark (to avoid pigment deterioration) before being crushed. The tests/spines were then pooled according to species and stored in the dark at $5^{\circ} \mathrm{C}$ before being extracted. Collection and sample preparation took place in the Halieutic and Marine Science Institute (University of Toliara, Madagascar), while the extraction and analyses were performed in the Biology of Marine Organisms and Biomimetics laboratory and the Organic Synthesis and Mass Spectrometry Laboratory of the University of Mons.

\subsubsection{Preparation of Crude Extracts from Sea Urchins}

For each experiment, $5 \mathrm{~g}$ of crushed tests/spines was macerated in $10 \mathrm{~mL}$ of a $6 \mathrm{M} \mathrm{HCl}$ solution for $1 \mathrm{~h}$ at room temperature to remove $\mathrm{CaCO}_{3}$ before being filtrated under vacuum with a Buchner flask. The solution was partitioned three times against diethyl ether $(v / v)$. The diethyl ether phases were recovered, pooled and partitioned three times against a $5 \% \mathrm{NaCl}$ solution $(w / v)$. Then, the ether phase was recovered and evaporated to dryness under low pressure at $60^{\circ} \mathrm{C}$ using a rotary evaporator (Laborota 4001 efficient, Heidolph, Germany), re-dissolved in $1 \mathrm{~mL}$ of $80 \%$ methanol and centrifuged at $10,000 \times g$ for $10 \mathrm{~min}$. Finally, the supernatant (corresponding to the "crude extract") was recovered and evaporated to dryness using a Speed Vac (RC 10.22, VWR international, Heverlee, Belgium), weighed and stored in the dark at $5{ }^{\circ} \mathrm{C}$ before analysis. The samples were dissolved in $80 \%$ methanol before mass spectrometry analyses and in Milli-Q water for bioassays. 


\subsubsection{Mass Spectrometry Analyses and Spinochrome Purification}

For the pigment isolation, a Waters Alliance 2695 liquid chromatography device (HPLC) was used. The system comprises a quaternary pump, a vacuum degasser and an autosampler. The chromatography was performed on a reverse phase column (Kinetex ${ }^{\circledR} 5 \mu \mathrm{m}$ Biphenyl $100 \AA$, $50 \times 4.6 \mathrm{~mm}$, Phenomenex, Torrance, CA, USA) at $30{ }^{\circ} \mathrm{C}$ with a sample volume injection of $25 \mu \mathrm{L}$ and a constant flow $(1.25 \mathrm{~mL} / \mathrm{min}$ ) of a gradient of eluent $\mathrm{A}$ (Water, $0.1 \%$ formic acid) and eluent $\mathrm{B}$ (Acetonitrile) (Table 5).

Table 5. Gradient timetable used for the HPLC separation.

\begin{tabular}{cccc}
\hline Time (Min) & Eluent A (\%) & Eluent B (\%) & Curve \\
\hline 00 & 80 & 20 & Equilibration \\
$00 \rightarrow 15$ & $80 \rightarrow 50$ & $20 \rightarrow 50$ & Linear gradient \\
$15 \rightarrow 16$ & $50 \rightarrow 80$ & $50 \rightarrow 80$ & Linear gradient \\
$16 \rightarrow 18$ & 80 & 20 & Isocratic \\
\hline
\end{tabular}

The HPLC device was coupled to a mass spectrometer to allow pigment identification and to select the retention time to manually collect the pigments. The mass spectra were obtained on a Waters Quattro Ultima using an Electrospray ionization (ESI) source in the negative ionization mode by scanning between $m / z 50$ and 1500. The ESI conditions were as follows: capillary voltage of $3.1 \mathrm{kV}$, cone voltage of $40 \mathrm{~V}$, source temperature of $120^{\circ} \mathrm{C}$ and desolvation temperature of $300{ }^{\circ} \mathrm{C}$. Dry nitrogen was used as the ESI gas with a flow rate of $50 \mathrm{~L} / \mathrm{h}$ for the gas cone and $500 \mathrm{~L} / \mathrm{h}$ for the desolvation gas.

To quantify the PHNQ in sea urchin tests/spines, 2-Hydroxy-1,4-naphthoquinone was chosen as an internal standard (IS). It was added to each sample at a concentration of $10 \mu \mathrm{G} / \mathrm{mL}$ to an $80 \%$ methanol solution. Identification and quantification were performed on crude extracts from the four species.

Accurate mass measurements allowing the prediction of the molecular formula of PHNQ ions were performed on a Waters Q-ToF Premier using ESI source, in the negative ionization mode by scanning between $m / z 50$ and 600 with scan durations of $1 \mathrm{~s}$ and an inter-scan times of $0.1 \mathrm{~s}$. The ESI conditions were as follows: capillary voltage of $3.1 \mathrm{kV}$, cone voltage of $40 \mathrm{~V}$, source temperature of $120^{\circ} \mathrm{C}$ and desolvation temperature of $300{ }^{\circ} \mathrm{C}$. Dry nitrogen was used as the ESI gas with a flow rate of $50 \mathrm{~L} / \mathrm{h}$ for the gas cone and $600 \mathrm{~L} / \mathrm{h}$ for the desolvation gas. The mass spectrometer was equipped with a lockspray source to obtain high mass accuracy for PHNQ ions. An iodide anion, $[\mathrm{I}]^{-}=126.9045$, generated from NaI aqueous solution upon ESI, was used as the lock mass. Mass spectra analyses were performed on MassLynx 4.1. mass spectrometry software (Waters, Milford, MA, USA).

As E. mathaei presents several highly concentrated PHNQ and could be easily collected, we selected this species for the purification of PHNQ for the biochemical tests. Four fractions of major spinochromes were collected at different times (Table 1) from numerous HPLC runs conducted with the E. mathaei crude extract (typical chromatogram in our previous study [5]). These 4 fractions correspond to Spinochrome E; Spinochrome B; Spinochrome A (which had a high purity) and a mix of Echinochrome A (75\%)/Spinochrome C (25\%), respectively. The Echinochrome A/Spinochrome C mix was constituted by two co-eluating molecules and was considered as one in our assays (molecular weight $(\mathrm{MW})=75 \%$ Echinochrome A $+25 \%$ Spinochrome C $=269.5 \mathrm{U})$. Each pigment fraction was evaporated to dryness using a Speed Vac (RC 10.22, VWR international) before being weighed and finally tested in each biochemical assay.

\subsection{Bioactive Effects of Spinochromes}

Antibacterial, antioxidant, inflammatory and cytotoxic activities of spinochromes were investigated to estimate their bioactive effects. In antibacterial and antioxidant assays, crude extracts from the four sea urchin species (E. mathaei, D. savignyi, T. gratilla and T. pileolus) and the four 
spinochromes isolated from the E. mathaei crude extract were tested. In inflammatory and cytotoxic assays, only the four isolated spinochromes were studied.

\subsubsection{Antibacterial Activity Assay}

For these tests, two model bacteria and three marine bacteria involved in biofilm formation were used. The first included the gram-negative Escherichia coli (Ehrenberg, 1835) and the gram-positive Bacillus subtilis (Ehrenberg, 1835) Cohn 1872 AL. E. coli was cultured in Lysogeny Broth (LB) (Merck, Overijse, Belgium) at $37^{\circ} \mathrm{C}, \mathrm{B}$. subtilis was cultured in CM0001 at $30^{\circ} \mathrm{C}$. The marine bacteria included: Cobetia marina (Cobet et al., 1970) Arahal et al., 2002 VL, Vibrio aesturianus Tison and Seidler, 1983 VP and Shewanella oneidensis Venkateswaran et al., 1999 VP. C. marina was cultured in CM0005 at $28^{\circ} \mathrm{C}$, V. aesturianus was cultured in CM0012 at $30^{\circ} \mathrm{C}$ and S. oneidensis was cultured in CM0014 at $28^{\circ} \mathrm{C}$. All strains were purchased from BCCM collection (Brussels, Belgium).

The assays were performed in 96-well plates by incubating $50 \mu \mathrm{L}$ of crude extract sample (4000-2 $\mu \mathrm{G} / \mathrm{mL}$ ) or isolated spinochromes $(2000-8 \mu \mathrm{M})$ in MilliQ water with $50 \mu \mathrm{L}$ of suspension of an actively growing culture of bacteria. MilliQ water was used as a negative control, and ampicillin at different concentrations was used as a positive control. Blanks corresponded to the sterile culture medium mixed with the tested sample. After incubating for $4 \mathrm{~h}$ at adequate temperature in a shaking incubator $(90 \mathrm{rpm})$, the absorbance was measured at $600 \mathrm{~nm}$. Bacterial growth (\%) was calculated using the following formula:

$$
\text { Bacterial growth }(\%)=100-\frac{A_{\text {sample }}-A_{\text {blank }}}{A_{\text {control }}-A_{\text {blank }}} \times 100
$$

where $A_{\text {sample }}$ is the absorbance measured after incubation, $A_{\text {blank }}$ is the absorbance of the blank and $A_{\text {control }}$ is the absorbance of the negative control as described above.

The $\mathrm{EC}_{50}$ (the half maximal effective concentration), i.e., the sample concentration necessary to decrease the bacterial growth by $50 \%$, was calculated from the results using a non-linear regression performed with the "Prism 6" (GraphPad) software (San Diego, CA, USA). The MIC (the Minimum Inhibitory Concentration), i.e., the sample concentration necessary to completely inhibit the bacterial growth, was calculated from the results using a non-linear regression based on the Lambert and Pearson method [79] and was performed with the "Prism 6" (GraphPad) software.

The effect of some high concentrations of purified spinochromes against $V$. aestruanus and C. marina is not shown because the bacteria/spinochrome mix formed dense clusters making the absorbance reading impossible. In these cases, after the experiment, the $100-\mu \mathrm{L}$ mix was suspended in $20 \mathrm{~mL}$ of medium and incubated overnight in order to determine the viability of bacteria by absorbance measurement.

\subsubsection{Antioxidant Activity Assay}

The antioxidant activity was measured using the DPPH radical-scavenging capacity. This classical method is based on the antioxidant capacity to reduce a purple-colored stable free radical, 2,2-diphenyl-1-picrylhydrazyl (DPPH). This capacity measurement is based on the absorbance of DPPH becoming pale yellowish-colored after the antioxidant reduction [80]. The assays were performed in 96-well plates by mixing $50 \mu \mathrm{L}$ of a solution of $160 \mu \mathrm{M}$ DPPH (Sigma Aldrich, St. Louis, MO, USA) in methanol with $50 \mu \mathrm{L}$ of the crude extract samples $(800-8 \mu \mathrm{G} / \mathrm{mL}$ in $100 \%$ methanol $-n=9$ for each concentration) or isolated spinochromes (240-0.08 $\mu \mathrm{M}$ in $100 \%$ methanol- $n=6$ for each concentration). Methanol mixed with DPPH was used as a negative control, and Trolox (Sigma Aldrich), a classic antioxidant analog of vitamin E, mixed with DPPH was used as a positive control. Blanks corresponded to methanol mixed with the tested sample without the DPPH. After incubation for $30 \mathrm{~min}$ at room 
temperature, the absorbance was measured at $560 \mathrm{~nm}$. The DPPH inhibition (\%) was calculated using the following formula:

$$
\text { DPPH inhibition (\%) }=100-\frac{A_{\text {sample }}-A_{\text {blank }}}{A_{\text {control }}-A_{\text {blank }}} \times 100
$$

where $A_{\text {sample }}$ is the absorbance measured after incubation, $A_{\text {blank }}$ is the absorbance of the blank as described above, and $A_{\text {control }}$ is the absorbance of the negative control. The EC $\mathrm{E}_{50}$, i.e., the sample concentration necessary to decrease the initial DPPH concentration by 50\%, was calculated from the results using a non-linear regression performed with the "Prism 6" (GraphPad) software.

\subsubsection{Inflammatory Activity}

The inflammatory activity was evaluated by the quantification of TNF- $\alpha$, an indicative cytokine for inflammatory responses, produced by J774 macrophages. J774 macrophages were cultured in Dulbecco's Modified Eagle's Medium (ref 41966-029; Thermofisher Scientific, Asse, Belgium) supplemented with $10 \%$ fetal bovine serum and $50 \mathrm{UI} / \mathrm{mL}$ Penicillin/Streptomycin (i.e., complete DMEM) in a humidified atmosphere at $37{ }^{\circ} \mathrm{C}$ with $5 \% \mathrm{CO}_{2}$. They were plated at a concentration of about $2.5 \times 10^{5}$ cells per $\mathrm{mL}$ in 24 -well plates and allowed to grow for $24 \mathrm{~h}$. The inflammatory activity was evaluated by replacing the medium by $1 \mathrm{~mL}$ of complete DMEM containing the different isolated spinochromes (100-1 $\mu \mathrm{M})$ solubilized in DMEM. After a one-hour incubation period, the macrophages were stimulated with $10 \mathrm{ng} / \mathrm{mL}$ lipopolysaccharide (LPS, Escherichia coli O55:B5, Sigma) in order to initiate the inflammatory response, and incubated again for $6 \mathrm{~h}$. Complete DMEM alone was used as a negative control. Cell-free supernatants were then harvested, centrifuged at $400 \times g$ for $5 \mathrm{~min}$ and stored at $-80^{\circ} \mathrm{C}$ for later TNF- $\alpha$ quantification. The TNF- $\alpha$ quantification was performed using a commercial ELISA kit according to the manufacturer's recommendations (eBiosciences).

\subsubsection{Cytotoxic Activity}

The cytotoxic activity was evaluated using Trypan Blue exclusion staining, which colors dead cells. HeLa cells (ATCC CCL-2) were cultured in Dulbecco's Modified Eagle's Medium (ref D6429; Sigma) supplemented with $100 \mathrm{UI} / \mathrm{mL}$ Penicillin, $100 \mu \mathrm{G} / \mathrm{mL}$ streptomycin and $2 \mathrm{mM}$ glutamine (i.e., complete DMEM) in a humidified atmosphere at $37{ }^{\circ} \mathrm{C}$ with $5 \% \mathrm{CO}_{2}$. The cells were plated at a concentration of about $5 \times 10^{4}$ cells per $\mathrm{mL}$ in 96-well plates and allowed to grow for $24 \mathrm{~h}$. Cell viability was evaluated by replacing the medium wit $200 \mu \mathrm{L}$ of the isolated spinochromes (500-100 $\mu \mathrm{M}$ ) solubilized in DMEM. DMEM alone was used as a negative control.

After an incubation period of $24 \mathrm{~h}$, the medium was removed, and the cells were detached from the plates using $100 \mu \mathrm{L}$ of $0.05 \%$ trypsin- $0.53 \mathrm{mM}$ Trypsin-EDTA (Gibco, Thermofisher Scientific, Asse, Belgium); $100 \mu \mathrm{L}$ of a $0.4 \%(w / v)$ trypan blue solution in water was added, mixed and allowed to stand for $5 \mathrm{~min}$. The cells were then counted using a Neubauer improved cell counting chamber. Then, $10 \mu \mathrm{L}$ of dye-cell suspension was loaded in both chambers of the hemocytometer, and 5 squares of each chamber were counted under a light microscope.

The cell viability (\%) was calculated using the following formula:

$$
\text { Cell viability }(\%)=\frac{C_{\text {alive }}}{C_{\text {total }}} \times 100
$$

where $C_{\text {alive }}$ is the count of living cells (i.e., non-stained cells) and $C_{\text {total }}$ is the count of total cells of the blank (that allows taking into account dead cells eliminated due to the medium removal after $24 \mathrm{~h}$ of incubation). The $\mathrm{EC}_{50}$, i.e., the spinochrome concentration necessary to decrease the cell viability by $50 \%$, was calculated from the results using a non-linear regression performed with the "Prism 6" (GraphPad) software. 
Acknowledgments: The authors thank the Institut Halieutique et des Sciences Marines (IH.SM) (Toliara, Madagascar) for allowing us to carry out sampling within their institute. This work was supported by a FRFC project (FNRS, Fonds National de la Recherche Scientifique). L.B. thanks the Franeau fund (UMONS), the fund Leopold III and the grant Agathon de Potter for financial support. P.F. is Research Director of the Fund for Scientific Research of Belgium (F.R.S.-FNRS). The MS laboratory is grateful to the "Fonds National pour le Recherche Scientifique" (FRS-FNRS) for financial support in the acquisition of the Waters QToF Premier mass spectrometer. This study is a contribution by the Centre Interuniversitaire de Biologie Marine (CIBIM).

Author Contributions: L.B., E.H. and L.F. conceived and designed the experiments; L.B. and L.F. performed the experiments; L.B. and G.C. analyzed the data; F.B., L.T., P.F., P.G., I.E. contributed reagents/materials/analysis tools; L.B. wrote the paper; All authors reviewed the paper.

Conflicts of Interest: The authors declare no conflict of interest.

\section{References}

1. Demain, A.L.; Fang, A. The natural functions of secondary metabolites. Adv. Biochem. Eng. Biotechnol. 2000, 69, 1-39. [CrossRef] [PubMed]

2. Caulier, G.; Flammang, P.; Gerbaux, P.; Eeckhaut, I. When a repellent becomes an attractant: Harmful saponins are kairomones attracting the symbiotic Harlequin crab. Sci. Rep. 2013, 3, 2639. [CrossRef] [PubMed]

3. Stonik, V.A.; Elyakov, G.B. Secondary Metabolites from Echinoderms as Chemotaxonomic Markers. In Bioorganic Marine Chemistry; Scheuer, P.P.J., Ed.; Springer: Berlin/Heidelberg, Germany, 1988; pp. 43-86.

4. Kornprobst, J.-M. Substances Naturelles D'Origine Marine-Tome 2; LAVOISIER S.A.S.: Cachan, France, 2005.

5. Brasseur, L.; Demeyer, M.; Decroo, C.; Caulier, G.; Flammang, P.; Gerbaux, P.; Eeckhaut, I. Identification and quantification of spinochromes in body compartments of Echinometra mathaei's colored types. Mar. Biol. 2017, submitted.

6. Service, M.; Wardlaw, A.C. Echinochrome-A as a bactericidal substance in the coelomic fluid of Echinus esculentus (L.). Comp. Biochem. Physiol. B Comp. Biochem. 1984, 79, 161-165. [CrossRef]

7. Thomson, R.H. Distribution of naturally occurring quinones. Pharm. World Sci. 1991, 13, 70-73. [CrossRef]

8. Mischenko, N.P.; Fedoreyev, S.A.; Pokhilo, N.D.; Anufriev, V.P.; Denisenko, V.A.; Glazunov, V.P. Echinamines A and B, first animated hydroxynaphthazarins from the sea urchin Scaphechinus mirabilis. J. Nat. Prod. 2005, 68, 1390-1393. [CrossRef] [PubMed]

9. Zhou, D.-Y.; Qin, L.; Zhu, B.-W.; Wang, X.D.; Tan, H.; Yang, J.F.; Li, D.M.; Dong, X.P.; Wu, H.T.; Sun, L.M.; et al. Extraction and antioxidant property of polyhydroxylated naphthoquinone pigments from spines of purple sea urchin Strongylocentrotus nudus. Food Chem. 2011, 129, 1591-1597. [CrossRef]

10. Stekhova, S.I.; Shentsova, E.B.; Kol'tsova, E.B.; Kulesh, N.I. Antimicrobial activity of polyhydroxynaphthoquinones from sea urchins. Antibiot. Khimioter. 1988, 33, 831-833. [PubMed]

11. Haug, T.; Kjuul, A.K.; Styrvold, O.B.; Sandsdalen, E.; Olsen, Ø.M.; Stensvåg, K. Antibacterial activity in Strongylocentrotus droebachiensis (Echinoidea), Cucumaria frondosa (Holothuroidea), and Asterias rubens (Asteroidea). J. Invertebr. Pathol. 2002, 81, 94-102. [CrossRef]

12. Shankarlal, S.; Prabu, K.; Natarajan, E. Antimicrobial and Antioxidant Activity of Purple Sea Urchin Shell (Salmacis virgulata L. Agassiz and Desor 1846). Am. J. Sci. Res. 2011, 6, 178-181.

13. Fusaro, R.M.; Runge, W.J.; Johnson, J.A. Protection against light sensitivity with dihydroxyacetone/ naphthoquinone. Int. J. Dermatol. 1972, 11, 67-70. [CrossRef] [PubMed]

14. Lebedev, A.V.; Levitskaya, E.L.; Tikhonova, E.V.; Ivanova, M.V. Antioxidant Properties, Autooxidation, and Mutagenic Activity of Echinochrome A Compared with Its Etherified Derivative. Biochemistry 2001, 66, 885-893. [CrossRef] [PubMed]

15. Lebedev, A.V.; Ivanova, M.V.; Levitsky, D.O. Echinochrome, a naturally occurring iron chelator and free radical scavenger in artificial and natural membrane systems. Life Sci. 2005, 76, 863-875. [CrossRef] [PubMed]

16. Kuwahara, R.; Hatate, H.; Yuki, T.; Murata, H.; Tanaka, R.; Hama, Y. Antioxidant property of polyhydroxylated naphthoquinone pigments from shells of purple sea urchin Anthocidaris crassispina. LWT Food. Sci. Technol. 2009, 42, 1296-1300. [CrossRef]

17. Kuwahara, R.; Hatate, H.; Chikami, A.; Murata, H.; Kijidani, Y. Quantitative separation of antioxidant pigments in purple sea urchin shells using a reversed-phase high performance liquid chromatography. LWT Food. Sci. Technol. 2010, 43, 1185-1190. [CrossRef] 
18. Li, D.-M.; Zhou, D.-Y.; Zhu, B.-W.; Miao, L.; Qin, L.; Dong, X.P.; Wang, X.D.; Murata, Y. Extraction, structural characterization and antioxidant activity of polyhydroxylated 1,4-naphthoquinone pigments from spines of sea urchin Glyptocidaris crenularis and Strongylocentrotus intermedius. Eur. Food Res. Technol. 2013, 237, 331-339. [CrossRef]

19. Lee, S.R.; Pronto, J.R.D.; Sarankhuu, B.-E.; Ko, K.S.; Rhee, B.D.; Kim, N.; Mishchenko, N.P.; Fedoreyev, S.A.; Stonik, V.A.; Han, J. Acetylcholinesterase inhibitory activity of pigment echinochrome A from sea urchin Scaphechinus mirabilis. Mar. Drugs 2014, 12, 3560-3573. [CrossRef] [PubMed]

20. Powell, C.; Hughes, A.D.; Kelly, M.S.; Conner, S.; McDougall, G.J. Extraction and identification of antioxidant polyhydroxynaphthoquinone pigments from the sea urchin, Psammechinus miliaris. LWT Food Sci. Technol. 2014, 59, 455-460. [CrossRef]

21. Pozharitskaya, O.N.; Shikov, A.N.; Makarova, M.N.; Ivanova, S.A.; Kosman, V.M.; Makarov, V.G.; Bazgier, V.; Berka, K.; Otyepka, M.; Ulrichová, J. Antiallergic effects of pigments isolated from green sea urchin (Strongylocentrotus droebachiensis) shells. Planta Med. 2013, 79, 1698-1704. [CrossRef] [PubMed]

22. Lennikov, A.; Kitaichi, N.; Noda, K.; Mizuuchi, K.; Ando, R.; Dong, Z.; Fukuhara, J.; Kinoshita, S.; Namba, K.; Ohno, S.; et al. Amelioration of endotoxin-induced uveitis treated with the sea urchin pigment echinochrome in rats. Mol. Vis. 2014, 20, 171-177. [PubMed]

23. Sciani, J.M.; Zychar, B.C.; Gonçalves, L.R.D.C.; Nogueira, T.D.O.; Giorgi, R.; Pimenta, D.C. Pro-inflammatory effects of the aqueous extract of Echinometra lucunter sea urchin spines. Exp. Biol. Med. 2011, 236, 277-280. [CrossRef] [PubMed]

24. Suárez-Peñaranda, J.M.; Vieites, B.; Del Río, E.; Ortiz-Rey, J.A.; Antón, I. Histopathologic and immunohistochemical features of sea urchin granulomas. J. Cutan. Pathol. 2013, 40, 550-556. [CrossRef] [PubMed]

25. Shapiro, H. The Extracellular Release of Echinochrome. J. Gen. Physiol. 1946, 29, 267-275. [CrossRef] [PubMed]

26. Tanaka, Y. Distribution and redistribution of pigment granules in the development of sea urchin embryos. Wilhelm Roux's Arch. Dev. Biol. 1981, 190, 267-273. [CrossRef] [PubMed]

27. Floyd, R.A. Antioxidants, oxidative stress, and degenerative neurological disorders. Soc. Exp. Biol. Med. 1999, 222, 236-245. [CrossRef]

28. Pham-huy, L.A.; He, H.; Pham-huy, C. Free Radicals, Antioxidants in Disease and Health. Int. J. Biomed. Sci. 2008, 4, 89-96. [PubMed]

29. Uttara, B.; Singh, A.V.; Zamboni, P.; Mahajan, R.T. Oxidative Stress and Neurodegenerative Diseases: A Review of Upstream and Downstream Antioxidant Therapeutic Options. Curr. Neuropharmacol. 2009, 7, 65-74. [CrossRef] [PubMed]

30. Kovaleva, M.A.; Ivanova, S.A.; Makarova, M.N.; Pozharitskaia, O.N.; Shikov, A.N.; Makarov, V.G. Effect of a complex preparation of sea urchin shells on blood glucose level and oxidative stress parameters in type II diabetes model. Eksp. Klin. Farmakol. 2013, 76, 27-30. [PubMed]

31. Egorov, E.A.; Alekhina, V.A.; Volobueva, T.M.; Fedoreev, S.A.; Mishchenko, N.P.; Kol'tsova, E.A. Histochrome, a new antioxidant, in the treatment of ocular diseases. Vestnik Oftalmol. 1999, 115, 34-35.

32. Soleimani, S.; Moein, S.; Yousefzadi, M.; Bioki, N.A. Determination of In Vitro Antioxidant Properties, Anti-inflammatory Effects and A-Amylase Inhibition of Purple Sea Urchin Extract of Echinometra Mathaei from the Persian Gulf. Jundishapur J. Nat. Pharm. Prod. 2016, in press. [CrossRef]

33. Shikov, A.N.; Ossipov, V.I.; Martiskainen, O.; Pozharitskaya, O.N.; Ivanova, S.A.; Makarov, V.G. The offline combination of thin-layer chromatography and high-performance liquid chromatography with diode array detection and micrOTOF-Q mass spectrometry for the separation and identification of spinochromes from sea urchin (Strongylocentrotus droebachi. J. Chromatogr. A 2011, 1218, 9111-9114. [CrossRef] [PubMed]

34. Hou, Y.; Shavandi, A.; Carne, A.; Bekhit, A.A.; Ng, T.B.; Cheung, R.C.F.; Bekhit, A.E.D.A. Marine shells: Potential opportunities for extraction of functional and health-promoting materials. Crit. Rev. Environ. Sci. Technol. 2016, 46, 1047-1116. [CrossRef]

35. Khamala, C.P.M. Ecology of Echinometra mathaei (Echinoidea: Echinodermata) at Diani Beach, Kenya. Mar. Biol. 1971, 11, 167-172. [CrossRef]

36. McClanahan, T.R.; Muthiga, N.A. Ecology of Echinometra. In Edible Sea Urchins: Biology and Ecology; Lawrence, J.M., Ed.; Elsevier: Amsterdam, The Netherlands, 2007; pp. 297-317. 
37. Muthiga, N.A.; McClanahan, T.R. Ecology of Diadema. In Edible Sea Urchins: Biology and Ecology; Lawrence, J.M., Ed.; Elsevier: Amsterdam, The Netherlands, 2007; pp. 205-225.

38. Vaïtilingon, D. The Biology and Ecology of the Echinoid Tripneustes Gratilla (Linneaus, 1758) off Toliara (Madagascar): Feeding, Reproduction, Larval Dévelopment, Population Dynamiics and Parasitism; Université Libre de Bruxelles: Bruxelles, Belgium, 2004.

39. Ziegenhorn, M.A. Best Dressed Test: A Study of the Covering Behavior of the Collector Urchin Tripneustes gratilla. PLoS ONE 2016, 11, e0153581. [CrossRef] [PubMed]

40. Chen, A.; Soong, K. “Uncovering” behavior at spawning of the trumpet sea urchin Toxopneustes pileolus. Zool. Stud. 2010, 49, 9.

41. Claereboudt, E.J.S.; Claereboudt, M.R. Quantifying sea urchins covering behavior by image analysis. Cah. Biol. Mar. 2013, 54, 587-592.

42. Thormann, K.M.; Saville, R.M.; Shukla, S.; Pelletier, D.A.; Spormann, A.M. Initial Phases of Biofilm Formation in Initial Phases of Biofilm Formation in Shewanella oneidensis MR-1. J. Bacteriol. 2004, 186, 8096-8104. [CrossRef] [PubMed]

43. Azandegbe, A. Etude de la Structure des Communautés Bactériennes du Sédiment et de L'Ecologie de Vibrio Aestuarianus Pathogène de L'Huître Creuse Crassostrea Gigas dans deux Sites Ostréicoles; Université de Brest: Brest, France, 2010.

44. Mieszkin, S.; Martin-Tanchereau, P.; Callow, M.E.; Callow, J.A. Effect of bacterial biofilms formed on fouling-release coatings from natural seawater and Cobetia marina, on the adhesion of two marine algae. Biofouling 2012, 28, 953-968. [CrossRef] [PubMed]

45. Blois, M. Antioxidant Determinations by the Use of a Stable Free Radical. Nature 1958, 181, 1199-1200. [CrossRef]

46. Fernandes, C.A.; Fievez, L.; Neyrinck, A.M.; Delzenne, N.M.; Bureau, F.; Vanbever, R. Biochemical and Biophysical Research Communications Sirtuin inhibition attenuates the production of inflammatory cytokines in lipopolysaccharide-stimulated macrophages. Biochem. Biophys. Res. Commun. 2012, 420, 857-861. [CrossRef] [PubMed]

47. Strober, W. Trypan Blue Exclusion Test of Cell Viability. Curr. Protoc. Immunol. 2001, 111, A3-B. [CrossRef]

48. Bellamakondi, P.K.; Godavarthi, A.; Ibrahim, M.; Kulkarni, S.; Naik, R.M.; Maradam, S. In Vitro cytotoxicity of caralluma species by MTT and trypan blue dye exclusion. Asian J. Pharm. Clin. Res. 2014, 7, 7-9.

49. Strober, W. Trypan Blue Exclusion Test of Cell Viability. Curr. Protoc. Immunol. 2015, 111, A3-B. [CrossRef] [PubMed]

50. Anderson, H.A.; Mathieson, J.W.; Thomson, R.H. Distribution of spinochrome pigments in echinoids. Comp. Biochem. Physiol. 1969, 28, 333-345. [CrossRef]

51. Thomson, R.H. Naturally Occuring Quinones, 2nd ed.; Academic Press Inc.: New York, NY, USA, 1971.

52. Hatate, H.; Murata, H.; Hama, Y.; Tanaka, R.; Suzuki, N. Antioxidative activity of spinochromes extracted from shells of sea urchins. Fish Sci. 2002, 68, 1641-1642. [CrossRef]

53. McClanahan, T.R.; Muthiga, N.A. Patterns of preedation on a sea urchin, Echinometra mathaei (de Blainville), on Kenyan coral reefs. J. Exp. Mar. Biol. Ecol. 1989, 126, 77-94. [CrossRef]

54. Sala, E. Fish predators and scavengers of the sea urchin Paracentrotus lividus in protected areas of the north-west Mediterranean Sea. Mar. Biol. 1997, 129, 531-539. [CrossRef]

55. Jangoux, M. Diseases of echinoderms. Helgol. Meeresunters. 1984, 37, 207-216. [CrossRef]

56. Jangoux, M. Diseases of Echinodermata. III. Agents metazoans (Annelida to Pisces). Dis. Aquat. Organ. 1987, 3, 59-83. [CrossRef]

57. Vaïtilingon, D.; Eeckhaut, I.; Fourgon, D.; Jangoux, M. Population dynamics, infestation and host selection of Vexilla vexillum, an ectoparasitic muricid of echinoids, in Madagascar. Dis. Aquat. Organ. 2004, 61, 241-255. [CrossRef] [PubMed]

58. Becker, P.T.; Egea, E.; Eeckhaut, I. Characterization of the bacterial communities associated with the bald sea urchin disease of the echinoid Paracentrotus lividus. J. Invertebr. Pathol. 2008, 98, 136-147. [CrossRef] [PubMed]

59. Becker, P.T.; Gillan, D.C.; Eeckhaut, I. Characterization of the bacterial community associated with body wall lesions of Tripneustes gratilla (Echinoidea) using culture-independent methods. J. Invertebr. Pathol. 2009, 100, 127-130. [CrossRef] [PubMed]

60. Shikov, A.N.; Ossipov, V.I.; Karonen, M.; Pozharitskaya, O.N.; Krishtopina, A.S.; Makarov, V.G. Comparative stability of dimeric and monomeric pigments extracted from sea urchin Strongylocentrotus droebachiensis. Nat. Prod. Res. 2017, 6419, 1-5. [CrossRef] [PubMed] 
61. Becker, P.; Gillan, D.; Eeckhaut, I. Microbiological study of the body wall lesions of the echinoid Tripneustes gratilla. Dis. Aquat. Organ. 2007, 77, 73-82. [CrossRef] [PubMed]

62. Nakagawa, H.; Tanigawa, T.; Tomita, K.; omihara, Y.; Araki, Y.; Tachikawa, E. Recent Studies on the Pathological Effects of Purified Sea Urchin Toxins. J. Toxicol. Toxin Rev. 2003, 22, 633-649. [CrossRef]

63. Akinbowale, O.L.; Peng, H.; Barton, M.D. Antimicrobial resistance in bacteria isolated from aquaculture sources in Australia. J. Appl. Microbiol. 2006, 100, 1103-1113. [CrossRef] [PubMed]

64. Kathleen, M.M.; Samuel, L.; Felecia, C.; Reagan, E.L.; Kasing, A.; Lesley, M.; Toh, S.C. Antibiotic Resistance of Diverse Bacteria from Aquaculture in Borneo. Int. J. Microbiol. 2016, 2016, 1-9. [CrossRef] [PubMed]

65. Lesser, M.P.; Farrell, J.H.; Walker, C.W. Oxidative stress, DNA damage and p53 expression in the larvae of atlantic cod (Gadus morhua) exposed to ultraviolet (290-400 nm) radiation. J. Exp. Biol. 2001, 204, 157-164. [PubMed]

66. Lesser, M.P.; Barry, T.M. Survivorship, development, and DNA damage in echinoderm embryos and larvae exposed to ultraviolet radiation (290-400 nm). J. Exp. Mar. Biol. Ecol. 2003, 292, 75-91. [CrossRef]

67. Lesser, M.P. Exposure to ultraviolet radiation causes apoptosis in developing sea urchin embryos. J. Exp. Biol. 2003, 206, 4097-4103. [CrossRef] [PubMed]

68. Asada, K. Production and Scavenging of Reactive Oxygen Species in Chloroplasts and Their Functions. Plant Physiol. 2006, 141, 391-396. [CrossRef] [PubMed]

69. Flora, S.J.S. Structural, Chemical and Biological Aspects of Antioxidants for Strategies Against Metal and Metalloid Exposure. Oxid. Med. Cell. Longev. 2009, 2, 191-206. [CrossRef] [PubMed]

70. Slavova-Kazakova, A.K.; Angelova, S.E.; Veprintsev, T.L.; Denev, P.; Fabbri, D.; Dettori, M.A.; Kratchanova, M.; Naumov, V.V.; Trofimov, A.V.; Vasil'ev, R.F.; et al. Antioxidant potential of curcumin-related compounds studied by chemiluminescence kinetics, chain-breaking efficiencies, scavenging activity (ORAC) and DFT calculations. Beilstein J. Org. Chem. 2015, 11, 1398-1411. [CrossRef] [PubMed]

71. Pozharitskaya, O.N.; Ivanova, S.A.; Shikov, A.N.; Makarov, V.G. Evaluation of Free Radical-Scavenging Activity of Sea Urchin Pigments Using HPTLC with Post-Chromatographic Derivatization. Chromatographia 2013, 76, 1353-1358. [CrossRef]

72. Inoue, K.; Takano, H.; Hiyoshi, K.; Ichinose, T.; Sadakane, K.; Yanagisawa, R.; Tomura, S.; Kumaga, Y. Naphthoquinone enhances antigen-related airway inflammation in mice. Eur. Respir. J. 2006, 29, $259-267$. [CrossRef] [PubMed]

73. Bodet, C.; Chandad, F.; Grenier, D. Hemoglobin and LPS Act in Synergy to Amplify the Inflammatory Response. J. Dent. Res. 2007, 86, 878-882. [CrossRef] [PubMed]

74. Smith, L.C.; Britten, R.J.; Davidson, E.H. Lipopolysaccharide activates the sea urchin immune system. Dev. Comp. Immunol. 1995, 19, 217-224. [CrossRef]

75. Nair, S.V.; Del Valle, H.; Gross, P.S.; Terwilliger, D.P.; Smith, L.C. Macroarray analysis of coelomocyte gene expression in response to LPS in the sea urchin. Identification of unexpected immune diversity in an invertebrate. Physiol. Genom. 2005, 22, 33-47. [CrossRef] [PubMed]

76. Majeske, A.J.; Bayne, C.J.; Smith, L.C. Aggregation of Sea Urchin Phagocytes Is Augmented In Vitro by Lipopolysaccharide. PLoS ONE 2013, 8, e61419. [CrossRef] [PubMed]

77. Gonzalez-Aravena, M.; Perez-troncoso, C.; Urtubia, R.; Branco, P.; Da Silva, J.R.M.C.; Mercado, L.; De Lorgeril, J.; Bethke, J.; Paschke, K. Immune response of the Antarctic sea urchin Sterechinus neumayeri: Cellular, molecular and physiological approach. Rev. Biol. Trop. 2015, 63, 309-320. [CrossRef]

78. Ioset, J.-R.; Brun, R.; Wenzler, T.; Kaiser, M.; Yardley, V. Drug Screening for Kinetoplastid Diseases: A Training Manual for Screening in Neglected Diseases; DNDi and Pan-Asian Screening Network: London, UK, 2009.

79. Lambert, R.J.W.; Pearson, J. Susceptibility testing: Accurate and reproducible minimum inhibitory concentration (MIC) and non-inhibitory concentration (NIC) values. J. Appl. Microbiol. 2000, 88, 784-790. [CrossRef] [PubMed]

80. Kedare, S.B.; Singh, R.P. Genesis and development of DPPH method of antioxidant assay. J. Food Sci. Technol. 2011, 48, 412-422. [CrossRef] [PubMed]

(C) 2017 by the authors. Licensee MDPI, Basel, Switzerland. This article is an open access article distributed under the terms and conditions of the Creative Commons Attribution (CC BY) license (http:/ / creativecommons.org/licenses/by/4.0/). 